\title{
Perpustakaan Desa Terhadap Minat Baca Lingkungan Desa Muara Bakti, Kabupaten Bekasi
}

\author{
Pratiwi Nila Sari ${ }^{1}$, Cahyadi Husadha ${ }^{1, \star}{ }^{\star}$, Raden Achmad Haryanto ${ }^{1}$, Andrian ${ }^{1}$, Ery Teguh \\ Prasetyo ${ }^{1}$, Istianingsih ${ }^{1}$ \\ ${ }^{1}$ Fakultas Ekonomi dan Bisnis, Universitas Bhayangkara Jakarta Raya; Jl. Raya \\ Perjuangan, MargaMulya, Bekasi Utara, Jawa Barat 17121. Telp: 021-88955882, 889955883; \\ e-mail: pratiwi@ubharajaya.ac.id, cahyadi.husadha@dsn.ubharajaya.ac.id, \\ raden.achmad@dsn.ubharajaya.ac.id, andriantahar@gmail.com, ery.teguh@ubharajaya.ac.id, \\ istianingsih@ubharajaya.ac.id \\ * Korespondensi: e-mail: cahyadi.husadha@dsn.ubharajaya.ac.id
}

Submitted: 30/06/2020; Revised: 05/01/2021; Accepted: 12/01/2021; Published: 29/01/2021

\begin{abstract}
Community Service Activities (PkM) here aim to provide education, knowledge, information and understanding to the wider community. Especially for elementary school students who live in Muara Bakti Village, Bekasi Regency, to foster interest in reading, reading habits, and stretching to read actively through the Village Library. The activity method used in implementing PKM activities here is to provide counseling to the Muara Bakti 01 Babelan-Bekasi State Elementary School, to explain the importance of fostering reading interest, reading habits, and stretching to read diligently. This of course aims to improve class achievement. This activity involves lecturers and students from various faculties in the Bhayangkara University Jakarta Raya environment.
\end{abstract}

Keywords: Habits, Libraries, Reading Interest, Stretching

\begin{abstract}
Abstrak
Kegiatan Pengabdian kepada Masyarakat (PkM) disini bertujuan untuk memberikan edukasi, pengetahuan, informasi, dan pemahaman kepada masyarakat luas. Terutama bagi siswa dan siswi sekolah dasar yang berdomisili di Desa Muara Bakti Kabupaten Bekasi untuk menumbuhkan minat baca, kebiasaan membaca, dan geliat untuk giat membaca melalui Perpustakaan Desa. Metode kegiatan yang dipergunakan dalam pelaksanaan kegiatan PKM disini adalah dengan melakukan penyuluhan ke sekolah Dasar (SD) Negeri Muara Bakti 01 Babelan-Bekasi, untuk menjelaskan tentang pentingnya menumbuhkan minat baca, kebiasaan membaca, dan geliat untuk rajin membaca. Hal ini tentunya bertujuan agar dapat meningkatkan prestasi di kelas. Adapun Kegiatan ini melibatkan para dosen dan mahasiswa dari berbagai fakultas di lingkungan Universitas Bhayangkara Jakarta Raya.
\end{abstract}

Kata kunci: Kebiasaan, Perpustakaan, Minat-Baca, Geliat

\section{Pendahuluan}

Sejalan dengan pesatnya laju pembangunan, jumlah penduduk Indonesia dari tahun ke tahun juga mengalami peningkatan yang cukup berarti. Melalui jalur pendidikan baik formal mulai dari pendidikan dasar, sekolah menengah sampai dengan pendidikan tinggi, maupun non formal pemerintah bertekad untuk membekali masyarakat sehingga mampu hidup layak. 
Pratiwi Nila Sari, Cahyadi Husadha, Raden Achmad Haryanto, Andrian, Ery Teguh Prasetyo, Istianingsih

Kita ketahui bahwa pendidikan memiliki peran penting dalam kemajuan sumber daya manusia yang dapat mengantarkan generasi selanjutnya pada masa depan yang cemerlang. Sesuai dengan Pembukaan UUD 1945 berbunyi pada alinea keempat tersirat kalimat mencerdaskan kehidupan bangsa..." didukung pula dengan Pasal 31 yang berbunyi "setiap warga negara berhak mendapatkan pendidikan" (http://www.bpkp.go.id/, 2020).

Dilihat dari segi sosial masyarakat setelah adanya industri di Desa Muara Bakti, kehidupan sosial masyarakat mengalami perubahan. (K Anwar, 2018). Sebagian besar masyarakat di Desa Muara Bakti telah mendapatkan pendidikan yang layak hanya saja peran orang tua dan guru masih kurang maksimal dalam memotivasi belajar pada siswa ataupun pada anak. Terlihat pada saat pembelajaran, masih banyak siswa yang sulit berkonsentrasi pada saat belajar, cenderung untuk mengganggu temannya pada saat belajar dibandingkan fokus dengan materi ataupun mengerjakan tugas yang diarahkan oleh guru. Minat siswa dalam belajar cenderung kurang, sering terlihat anak-anak lebih menyenangi bermain daripada belajar.

Minat baca masyarakat Indonesia dinilai masih rendah dibandingkan dengan negaranegara lain. UNESCO mencatat pada 2012 indeks minat baca di Indonesia baru mencapai 0,001 artinya dalam 1000 orang hanya ada satu orang yang berkegiatan membaca.(Nafisah, 2014). Secara teoritis ada hubungan yang positif antara minat baca (reading interest) dengan kebiasaan membaca (reading habit) dan kemampuan membaca (reading ability). Membaca memang lebih sulit bila dibandingkan dengan melihat atau mendengar. Membaca membutuhkan kemampuan untuk memahami rangkaian kalimat kemudian menafsirkannya sendiri tanpa bantuan orang lain, dan tidak semua orang punya cukup kesabaran untuk melakukan hal semacam itu. Budaya gemar membaca dalam masyarakat kita masih rendah dan memprihatinkan. Kita masih tersedot pada tradisi mendengar dan menutur, belum beralih ke masyarakat maju yang suka membaca dan menulis (Sudarsana, 2014).

Di dalam UU Nomor 43 Tahun 2007 Perpustakaan Umum adalah perpustakaan yang diperuntukkan bagi masyarakat luas sebagai sarana pembelajaran tanpa membedakan umur, jenis kelamin, suku, ras, agama dan status sosial ekonomi. Salah satu contoh perpustakaan umum yaitu Perpustakaan Desa. (https://peraturan.bpk.go.id/, 2007). Perpustakaan Desa adalah lembaga layanan publik yang berada di desa yang dikembangkan dan diolah oleh masyarakat dan digunakan untuk masyarakat sekitar. Melalui perpustakaan setiap orang dari berbagai masyarakat dapat menumbuhkan minat baca tanpa harus pergi ke sekolah. Dengan hal itu, tanpa harus menempuh pendidikan formal seseorang dapat menggali ilmu dengan cara memaksimalkan keberadaan fungsi perpustakaan. Sasaran pendidikan nonformal dalam Perpustakaan Desa adalah pemustaka, yaitu bagaimana perpustakaan memberikan ilmu pengetahuan atau ketrampilan bagi pemustaka (Holifatul Mukharomah, Yaqub Cikusin, 2019). Perpustakaan desa berperan dalam menyediakan kebutuhan informasi masyarakat, memperbaiki kesejahteraan masyarakat di sekitarnya, menyediakan buku-buku pengetahuan 
maupun keterampilan untuk mendukung keberhasilan kegiatan masyarakat. Sehingga mereka mempunyai bekal dalam pengembangan diri (Maskurotunitsa \& Rohmiyati, 2016).

Di Indonesia bisa dikatakan sangat rendah dalam minat membaca. Menurut sumber data yang didapat, Indonesia peringkat 60 dari 61 negara yang menjadi objek penelitian lembaga Central Connectius State University pada tahun 2016. Berbagai laporan didapat dari lembaga kompeten, baik nasional maupun Internasional, baik pemerintah maupun nonpemerintah, menunjukkan bahwa Indeks minat baca masyarakat Indonesia masih tergolong rendah dan memprihatinkan (Holifatul Mukharomah, Yaqub Cikusin, 2019). Pemberdayaan masyarakat melalui perpustakaan dapat dilakukan, yaitu dengan meningkatkan minat terhadap buku atau bacaan. Minat baca yang tinggi menjadikan seseorang dapat memperoleh informasi dari bacaan yang dibacanya dalam rangka meningkatkan pengetahuan. Minat baca dapat ditumbuhkan dengan menanamkan kebiasaan membaca kepada seseorang, yang nantinya diharapkan lama-kelamaan akan terbiasa dan menjadi budaya baca bagi dirinya sendiri. Dengan timbulnya budaya baca pada seseorang maka akan timbul rasa keingintahuan akan pengetahuan yang dia miliki. Rasa keingintahuan akan pengetahuan dapat diperoleh dari koleksi buku yang tersedia pada sebuah perpustakaan (Maskurotunitsa \& Rohmiyati, 2016).

Pengabdian kepada masyarakat Universitas Bhayangkara Jakarta Raya merupakan salah satu bagian dari Tri Dharma Perguruan Tinggi. Dengan kegiatan pengabdian kepada masyarakat diharapkan dapat membangun generasi untuk sumber daya manusia menuju desa yang lebih unggul serta maju dengan kreatifitas dan inovatif dalam membangun sumber daya manusia yang ada di Desa Muara Bakti, Kecamatan Babelan, Kabupaten Bekasi.

Desa Muara Bakti merupakan salah satu desa yang berada di kecamatan Babelan, Kabupaten Bekasi, Jawa Barat. Desa ini memiliki kondisi wilayah yang berada di dataran dan merupakan wilayah perbatasan desa/kelurahan lain. Luas desa ini yaitu 539.76 Ha. Dengan luas wilayah daratan $233.56 \mathrm{Ha}$, luas wilayah Perairan $124.2 \mathrm{~km} 2$, luas tanah sawah $180 \mathrm{Ha}$ dan sisanya $2 \mathrm{Ha}$. Karakteristik wilayah desa ini merupakan dataran rendah dengan ketinggian 0-25 mdpl (http://muarabakti.com/index.php, 2020)

Desa Muara Bakti dihuni oleh 3057 kepala keluarga, dengan jumlah bayi dan balita 340 orang dan penduduk usia 7-12 tahun (siswa SD) sebesar 1100 orang. Usia 13-15 tahun (Siswa SMP) sebesar 780 orang. Usia 16-18 Tahun (Siswa SMK) sebanyak 620 orang. Sarana Pendidikan di desa ini yaitu Gedung TK/RA sebanyak 15 buah, Gedung SD/MI 10 buah, gedung SLTP/MTs sebanyak 11 buah, gedung SLTA/MA sebanyak 9 buah.

Dalam bidang Pendidikan khususnya di SDN 01 Muara Bakti, ada beberapa siswa siswi yang belum bisa membaca dengan baik dan kurang mengerti cara menghitung atau cara mengerjakan soal pelajaran matematika.

Implementasi pembelajaran tematik akan terwujud dan tercapai manakala guru dalam merencanakan, melaksanaakan dan mengevaluasi menguasai berbagai strategi/metode pembelajaran (Kholistin, 2008). Metode pembelajaran yang terjadi berfokus hanya pada buku tematik, sementara dibutuhkan buku panduan lain untuk membantu siswa dalam memahami 
Pratiwi Nila Sari, Cahyadi Husadha, Raden Achmad Haryanto, Andrian, Ery Teguh Prasetyo, Istianingsih

materi tersebut. Untuk memajukan bangsa tentu dibutuhkan kepekaan masyarakat terhadap pentingnya membaca. Menumbuhkan minat membaca pada usia dini perlu menjadi perhatian utama. Dibutuhkan lingkungan yang mendukung sang anak untuk mengenalkan dunia melalui jendela ilmu dengan begitu mereka mendapatkan wawasan dan terciptanya budaya gemar membaca.

Melihat permasalahan diatas membuat penulis tertarik untuk menentukan kegiatan program kerja yang berfokus pada pendidikan, lingkungan dan keseshatan sesuai dengan judul yakni "Perpustakaan Desa Terhadap Minat Baca Di Lingkungan Desa Muara Bakti, BabelanBekasi"

\section{Metode Penelitian}

Dalam menentukan dan melakukan suatu kegiatan terdapat tahap yang harus dilalui melalui metode agar dapat berjalan sesuai dengan tujuan dan capaian yang ingin diraih. Sebelum terjun ke lapangan kami melakukan survei lokasi untuk menentukan langkah selanjutnya Berdasarkan hasil pengamatan dan melalui wawancara dengan Wakil Kepala Desa Muara Bakti Menanyakan kegiatan apa saja yang terjadi di Desa Muara Bakti sekaligus melapor dan meminta izin untuk melakukan kegiatan Pengabdian Kepada Masyarakat di Desa Muara Bakti. Kami pun berusaha untuk mendekatkan diri pada orang tua mengenai permasalahan yang terjadi serta kesulitan orang tua dalam mengajar anak karena hambatan pada wawasan orang tua. Dari sisi kepedulian orang tua terhadap Pendidikan sang anak masih kurang peduli terhadap mutu Pendidikan anak, masih lebih banyak waktu anak untuk bermain daripada belajar.

Metode pelatihan terhadap minat baca di SD 01 Babelan ini, pertama-tama dijelaskan di dalam kelas dengan pendekatan kepada siswa-siswi dari kelas 1 (satu) sampai dengan kelas 6 (enam) yang dibantu oleh rekan-rekan dari mahasiswa sebanyak 10 orang. Melalui pendekatan secara langsung kepada siswa-siswi, masih ada beberapa dari mereka yang belum lancar membaca padahal siswa tersebut sudah kelas 3 (tiga) yang seharusnya mereka sudah lancar membaca dan berhitung.

Selain metode pelatihan di dalam kelas, kami juga mengadakan kegiatan di luar kelas yaitu di kantor Balai Desa Muara Bakti yang lokasinya bersebelahan dengan sekolah SD 01 Babelan. Kegiatan tersebut juga dibantu oleh mahasiswa kepada beberapa siswa dan siswi melakukan kerajinan tangan, menari dan belajar membaca serta berhitung. Anak-anak siswasiswi tersebut sangat antusias dengan kegiatan yang diadakan di Balai Desa.

Luaran yang diharapkan adalah dapat menjadi generasi penerus bangsa yang berkualitas melalui kegiatan program kerja yang telah disusun yaitu Mengajar, Bimbingan Belajar dan kegiatan lainnya seperti menari dan kerajinan tangan. Dalam kegiatan mengajar dan Bimbingan Belajar manfaat yang diperoleh adalah dapat bekerja sama dengan tim dan berani untuk mengekpresikan dirinya melalui cara bertanya pada saat tidak memahami serta menunjukkan potensi dalam diri masing-masing. 
Untuk memotivasi minat membaca bagi masyarakat di lingkungan Desa Muara Bakti, khususnya bagi siswa SDN 01 Babelan-Bekasi, maka kami membuat Perpustakaan Desa yang berada di Kantor Desa Muara Bakti, Babelan-Bekasi.

\section{Hasil dan Pembahasan}

\subsection{Persiapan Kegiatan}

Persiapan yang sudah dilakukan sebelum kegiatan pengabdian kepada masyarakat ini adalah sebagai berikut 1) Observasi. Melakukan pengamatan dan kunjungan ke Kantor Desa Muara Bakti, Kabupaten Bekasi Kecamatan Babelan, kemudian bertemu dengan Bapak Sekretaris Desa Bpk. Yudi beserta jajaran pengurus Kantor Desa Muara Bakti. Setelah itu, kami berkunjung ke SD 01 Babelan dan bertemu dengan Bapak Wakil Kepala Sekolah Bpk. Deden Nasrolih dan para guru SD 01 Babelan. 2) Tema Pengabdian. Berdasarkan atas apa yang telah dilakukan dalam survei yang diuraikan secara rinci pada latar belakang sehingga tema pengabdian dapat segera ditentukan yaitu Perpustakan Desa Terhadap Minat Baca di Lingkungan Desa Muara Bakti Babelan demi mewujudkan kualitas Sumber Daya Manusia yang unggul dan siswa-siswi berprestasi. 3) Minat baca di SD 01 Babelan. Pertama-tama dijelaskan di dalam kelas dengan pendekatan kepada siswa-siswi dari kelas 1 (satu) sampai dengan kelas 6 (enam) yang dibantu oleh rekan-rekan dari mahasiswa sebanyak 10 orang. Melalui pendekatan secara langsung kepada siswa-siswi, masih ada beberapa dari mereka yang belum lancar membaca padahal siswa tersebut sudah kelas 3 (tiga) yang seharusnya mereka sudah lancar membaca dan berhitung. Selain metode pelatihan di dalam kelas, kami juga mengadakan kegiatan di luar kelas yaitu di kantor Balai Desa Muara Bakti yang lokasinya bersebelahan dengan sekolah SD 01 Babelan. Kegiatan tersebut juga dibantu oleh mahasiswa kepada beberapa siswa dan siswi melakukan kerajinan tangan, menari dan belajar membaca serta berhitung. Para siswa-siswi tersebut sangat antusias dengan kegiatan yang diadakan di Balai Desa. Untuk itu, kami membuat Perpustakan Desa yang berlokasi di Kantor Desa Muara Bakti agar dapat bermanfaat bagi masyarakat di lingkungan Desa Muara Bakti.

\subsection{Jadwal Pelaksanaan Kegiatan}

Kegiatan pengabdian kepada masyarakat dengan tema "Perpustakan Desa Terhadap Minat Baca di Lingkungan Desa Muara Bakti Babelan", Kabupaten Bekasi, Kecamatan Babelan, dilaksanakan pada Hari Sabtu, tepatnya tanggal 23 Februari 2020, dimulai sejak pukul 08.00 - 15.00 WIB, yang bertempat di Ruang Pertemuan Balai Desa Muara Bakti Babelan dan Sekolah SD 01 Babelan-Bekasi. 


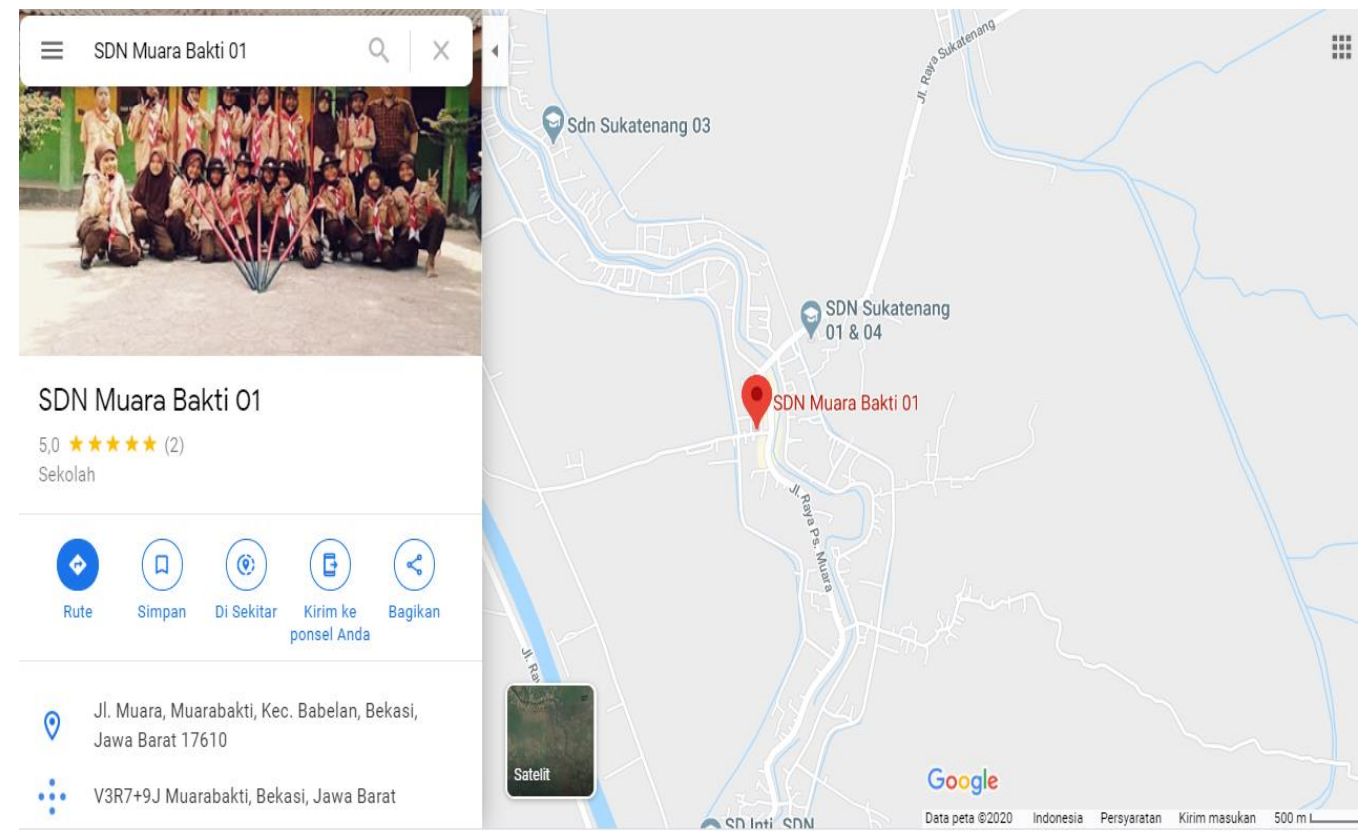

Sumber: Hasil Pelaksanaan (2020)

Gambar 1. Photo Lokasi SD 01 Babelan-Bekasi

Dalam pelaksanaan kegiatan pengabdian ini, Tim dosen bersama para mahasiswa, bersama peserta didik siswa-siswi SD 01 Babelan-Bekasi, serta Guru dan Pejabat pemerintah desa yang dapat terlihat pada gambar-gambar dibawah ini. Gambar pertama mahasiswa melakukan kegiatan geliat membaca bersama siswa-siswi, menjelaskan dan menuntun agar terus bersemangat dalam membaca. Gambar kedua dan ketiga, merupakan kegiatan pengajaran menyeluruh bersama siswa-siswi dalam hal kebiasaan membaca, memunculkan giat dan kiat dalam membaca, serta pentingnya mencari dan menambahkan informasi dalam bacaan yang dibaca. Gambar keempat merupakan kegiatan komunikasi langsung Tim dosen dan mahasiswa bersama guru dan pejabat pemerintah setempat dalam hal Peresmian Perpustakaan Desa yang aktif untuk kegiatan perpustakaan di desa setempat.

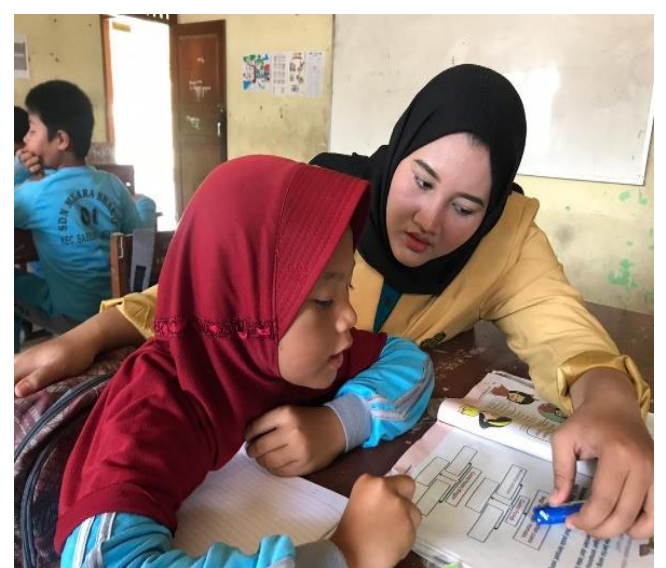

(1)

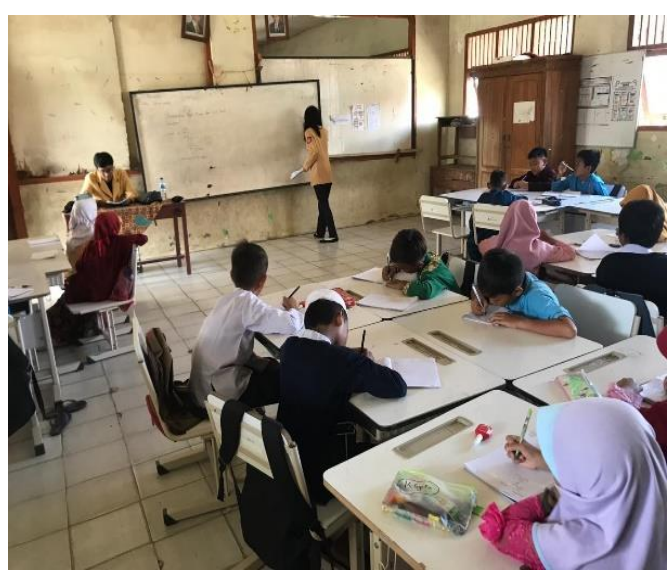

(2) 


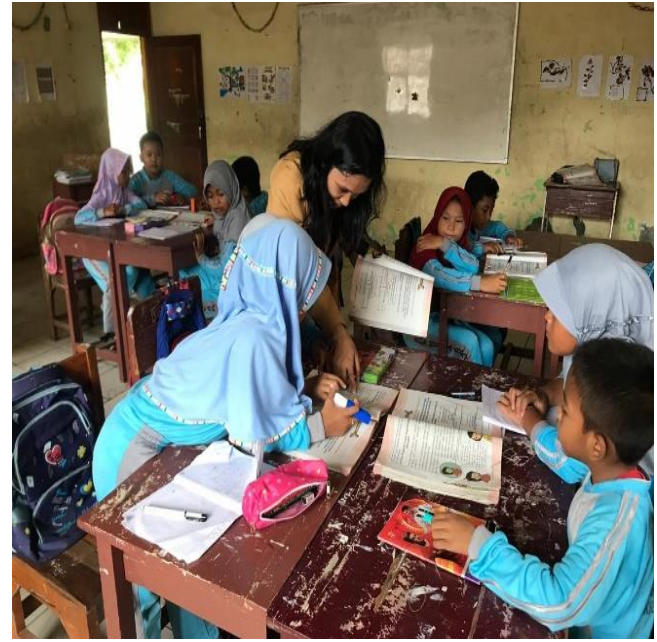

(3)

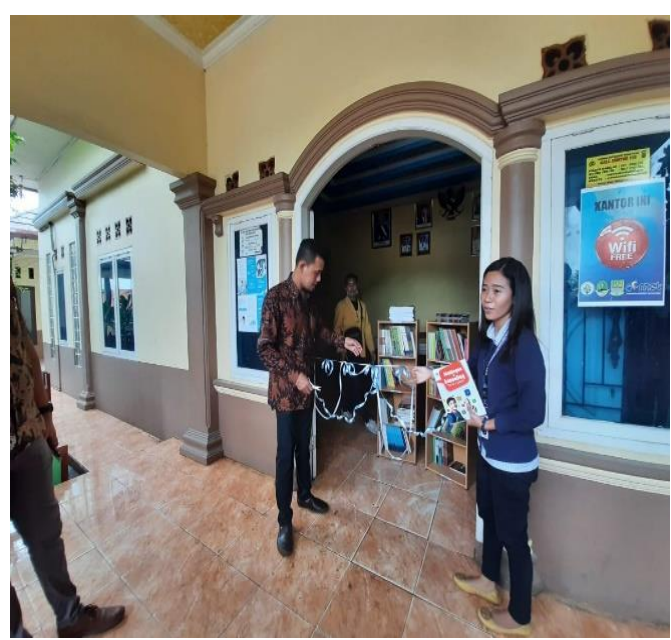

(4)

Sumber: Hasil Pelaksanaan (2020)

Gambar 2. Photo Kegiatan Penyampaian Materi dan Peresmian Perpustakaan Desa

Dan pada akhirnya, kegiatan pengabdian ini pun ditutup dengan penyerahan plakat dan kenang-kenangan kepada pejabat pemerintah desa setempat.

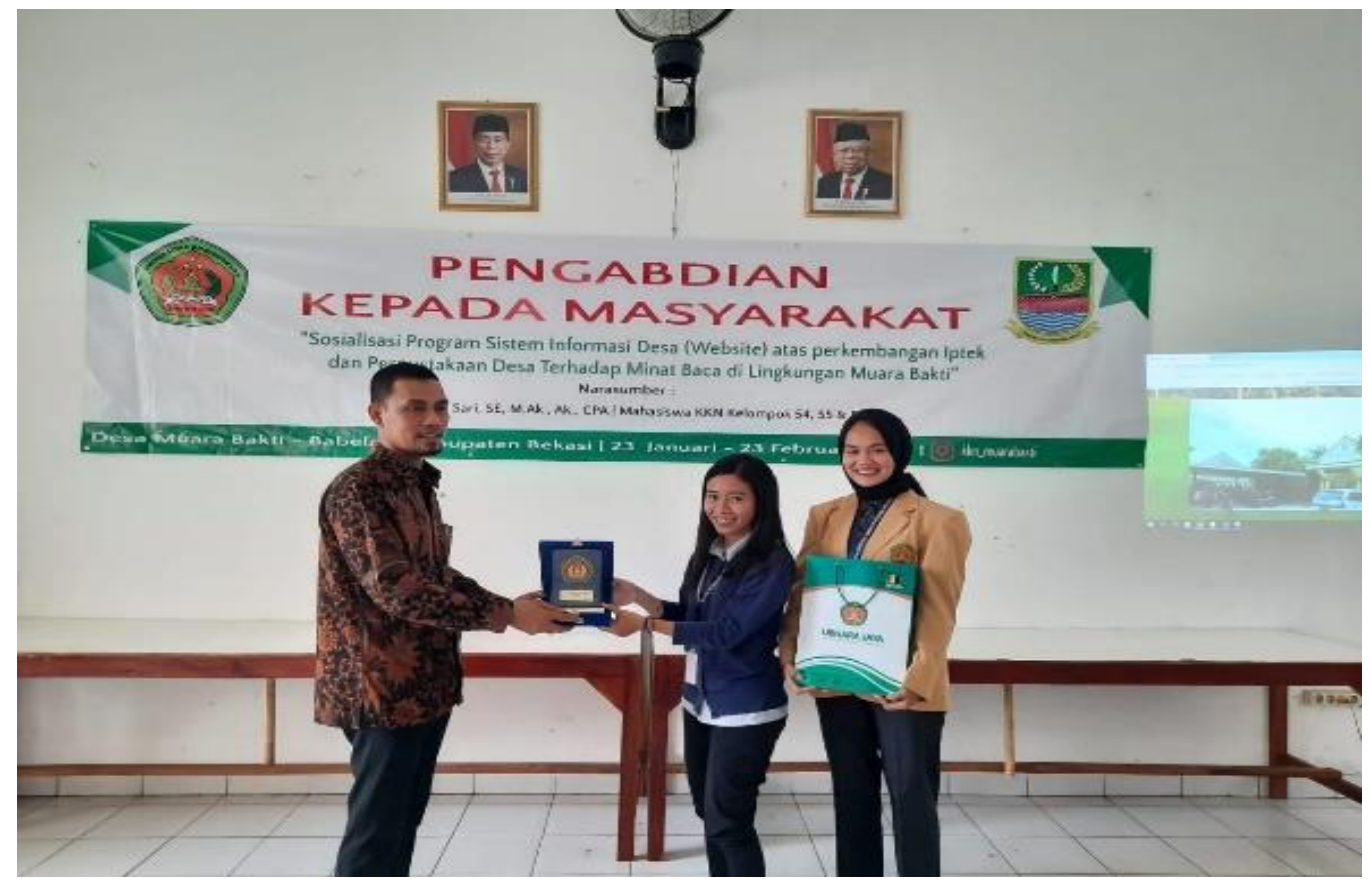

Sumber: Hasil Pelaksanaan (2020)

Gambar 3. Photo Kegiatan Pengabdian Masyarakat

Tim dosen bersama mahasiswa, sejak awal survey, dan diakhiri dengan perpisahan dari kegiatan pengabdian masyarakat, dilakkan di Kantor Balai Desa Muara Bakti, yang secara kebetulan, lokasinya bersebelahan dengan sekolah SD 01 Babelan-Bekasi. 


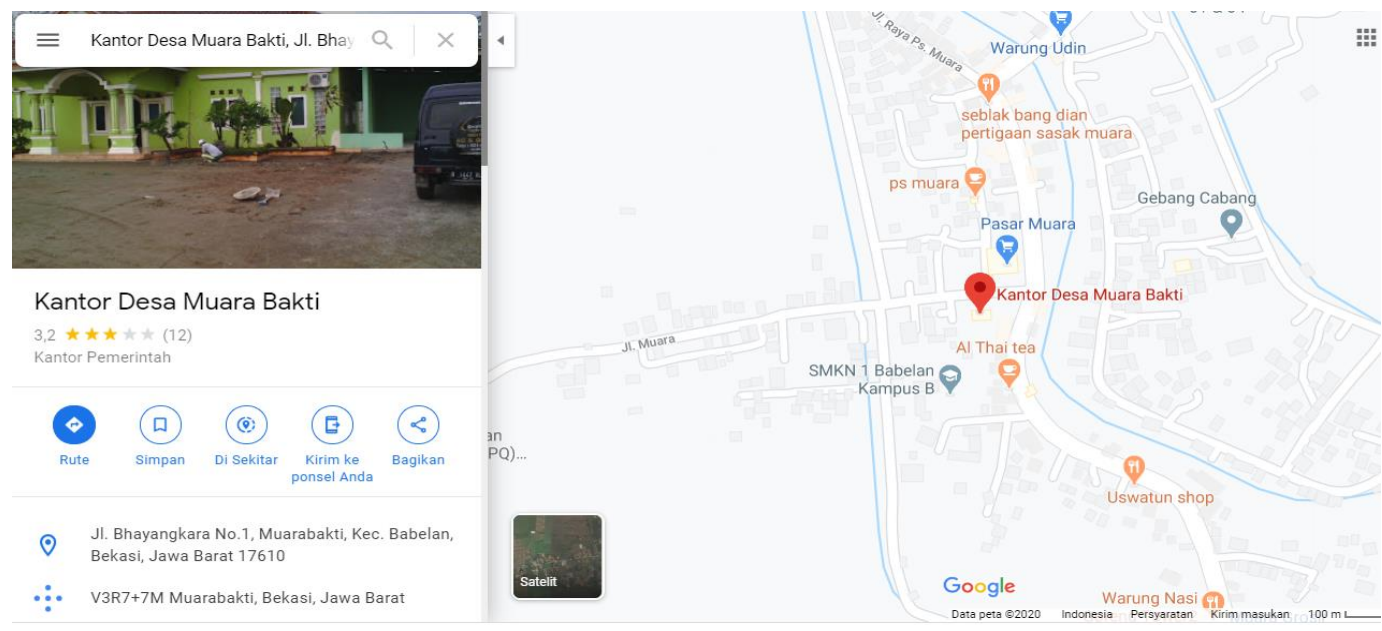

Sumber: Hasil Pelaksanaan (2020)

Gambar 4. Lokasi Kegiatan PKM Desa Muara Bakti Babelan, Bekasi

\subsection{Materi Pelatihan}

Kegiatan ini dihadiri oleh Sekretaris Desa Muara Bakti beserta jajaran pengurus, Wakil Kepala Sekolah, Bapak dan Ibu Guru Serta siwa-siswi SD 01 Babelan. Sedangkan dari Universitas Bhayangkara dihadiri oleh 5 orang dari Tim Dosen dan 10 orang Mahasiswa. Adapun kegiatan diawali dengan doa dan perkenalan oleh tim dosen kepada para peserta, lalu menjelaskan maksud dan tujuan kegiatan ini agar para peserta paham dan bertambah pengetahuannya. Setelah itu dilanjutkan dengan kata sambutan dari pihak Desa Muara Bakti yang di wakili oleh Bapak Sekretaris Desa dan dari pihak Sekolah SD 01 Babelan yang diwakili oleh Bapak Wakil Kepala Sekolah.

Adapun susunan acara kegiatan pengabdian kepada masyarakat adalah sebagai berikut: 1.) Diawali dengan pembukaan dari pihak Kantor Desa Muara Bakti, yang diwakili oleh Bpk. Yudi, selaku Sekretaris Desa Muara Bakti, Babelan; 2.) Mendengarkan secara bersama kata sambutan dari pihak Sekolah SD 01 Babelan, yang diwakili oleh Bpk. Deden, selaku Wakil Kepala Sekolah SD 01 Babelan; 3.) Dilanjutkan dengan kata sambutan dari perwakilan Tim Dosen dan Mahasiswa Universitas Bhayangkara Jakarta Raya, yang disampaikan oleh lbu Pratiwi Nila Sari SE, M.Ak., Ak., CPA selaku Ketua Pelaksana Kegiatan Pengabdian Kepada Masyarakat; 4.) Diakhiri dengan kata sambutan yang terakhir dari pihak Kantor Desa Muara Bakti, yang diwakili oleh Bpk. Yudi, selaku Sekretaris Desa Muara Bakti, Babelan; 5.) Dan pada akhiri dengan pembacaan Doa oleh perwakilan mahasiswa Universitas Bhayangkara Jakarta Raya; 6.) Paska acara formil, maka dilanjutkan dengan pelatihan yang disampaikan oleh team Dosen antara lain Bpk. Dr. Raden Achmad Harianto, Bpk. Cahyadi Husada, S.E., M.M., Bpk Ery Teguh S.E., M.M., dan Bpk. Andrian, S.E., M.M., Serta teman-teman dari mahasiswa yang berjumlah 10 orang dengan pendekatan kepada siswa dan siswi SD 01 Babelan. Mahasiswa dan jajaran pengurus Desa Muara Bakti mempersiapkan Perpustakaan Desa, seperti rak dan buku-buku bacaan; 7.) Usai pelaksanaan acara dan kegiatan di hari pertama dan berikutnya, maka sampailah pada hari Peresmian Perpustakaan Desa dengan gunting pita yang dilakukan 
secara bersama-sama oleh Bpk. Yudi selaku perwakilan dari Desa Muara Bakti dan Ibu Pratiwi Nila Sari selaku perwakilan dari Universitas Bhayangkara Jakarta Raya; 8.) Dan pada akhirnya, diakhiri dengan acara penutup dari Universitas Bhayangkara oleh Bpk. Ery Teguh, S.E., M.M., selaku Wakil Dekan III Fakultas Ekonomi; 9.) Kemudian penutupan dari pihak Kantor Desa Muara Bakti, yang diwakili oleh Bpk. Yudi, selaku Sekretaris Desa Muara Bakti, Babelan; 10.) Dilanjutkan dengan penutup dari pihak Sekolah SD 01 Babelan, yang diwakili oleh Bpk. Deden, selaku Wakil Kepala Sekolah serta bapak dan ibu guru dan siswa-siswi SD 01 Babelan.

\subsection{Indikator Keberhasilan Kegiatan PKM}

Jika rencana kegiatan Sama dengan pelaksanaan di lapangan, berarti dapat dikatakan sesuai dengan yang diharapkan atau dapat dikatakan berhasil. (Husadha et al., 2020) Ada beberapa indikator keberhasilan dalam penyelenggaraan kegiatan PKM diantaranya adalah: 1.) Dengan hadirnya perpustakaan desa yang tersedia di Kantor Desa Muara Bakti disini, diharapkan dapat memberikan sumbangsih atas ilmu-ilmu yang bermanfaat yang dapat diambil melalui buku-buku yang telah tersedia dan disediakan secara berkelanjutan sesuai dengan konteks kekinian; 2.) Siswa ataupun masyarakat sekitar, diharapakan dapat memiliki kemampuan dalam menggunakan perpustakan desa tersebut untuk tujuan menambah ilmu dan informasi; 3.) Dan pada akhirnya, bermuara kepada kami. Bagi kami selaku dosen-dosen peyelenggara pengabdian masyarakat ini adalah merupakan wujud pengejawantahan dari tri dharma perguruan tinggi yang merupakan bentuk pengabdian kami kepada masyarakat khususnya dalam hal ini pada siswa/siswi Sekolah Dasar 01 Babelan-Bekasi.

\section{Kesimpulan}

Dari kegiatan pengabdian kepada masyarakat ini diperoleh kesimpulan bahwa: a.) Dengan memberikan penyuluhan edukasi kepada siswa dan siswi di SD 01 Babelan melalui pendekatan di kelas betapa pentingnya membaca sehingga senang membaca; b.) Untuk meningkatkan daya tarik masyarakat maupun siswa/siswi SD 01 dan masyarakat sekitar di lingkungan Desa Muara Bakti dalam membaca, untuk itu kami memfasilitasi Perpustakaan Desa yang bertempat di Kantor Desa Muara Bakti.

Dalam keterbatasan waktu dan pengelolan, tim menyadari waktu dan biaya untuk pelatihan ini masih harus terus ditingkatkan untuk kegiatan PkM ini. Dan setelah adanya kegiatan ini, diharapkan ada keberlanjutan kepada warga masyarakat Desa Muara Bakti antara lain: a.) Meningkatkan motivasi belajar siswa dengan harapan dapat memberikan pengaruh pada prestasi siswa; b.) Memajukan siswa sehingga mendapatkan gambaran atas cita-cita yang ingin diraih; c.) Meningkatkan kesadaran membaca bagi masyarakat di lingkungan Desa Muara Bakti.

\section{Ucapan Terima Kasih (Opsional)}

Secara khusus rasa terimakasih tersebut kami sampaikan kepada: 1.) Irjen. Pol. (Purn) Dr. Drs. H. Bambang Karsono, S.H., M.M. selaku Rektor Universitas Bhayangkara Jakarta Raya yang 
telah memberikan arahan dan semangat bagi para Dosen untuk terus melakukan Penelitian dan Pengabdian Kepada Masyarakat demi kemajuan di Universitas Bhayangkara Jakarta Raya; 2.) Dr. Istianingsih, selaku Dekan Fakultas Ekonomi Universitas Bhayangkara Jakarta Raya, yang telah menyetujui untuk melakukan Pengabdian kepada masyarakat; 3.) Ir. Djuni Thamrin, Ph.D. selaku Kepala Lembaga Penelitian, Pengabdian Masyarakat dan Publikasi yang telah banyak memberikan arahan serta masukan dalam penyempurnaan Laporan Hasil Pengabdian Kepada Masyarakat; 4.) Prasojo, S.Sos., M.Si. selaku Kepala Bidang Pengabdian Kepada Masyarakat dan Kewirausahaan yang telah memberikan arahan serta masukan dalam penyempurnaan Proposal Pengabdian Kepada Masyarakat; 5.) Adelina Suryati, S.E., M.Ak. selaku Kepala Bagian Keuangan, Universitas Bhayangkara Jakarta Raya; 6.) Asmawi selaku Kepala Desa Muara Bakti Kecamatan Babelan Kabupaten Bekasi yang telah memberikan kesempatan kepada Tim dalam melaksakan kegiatan Pengabdian Kepada Masyarakat ini; 7.) Rekan-rekan Dosen yang telah memberikan masukan dan pencerahan dalam melakukan penelitian, yang tidak bisa saya sebutkan satu-satu.

\section{Daftar Pustaka}

Holifatul Mukharomah, Yaqub Cikusin, S. (2019). Peran Perpustakaan Desa Dalam Menumbuhkan Minat Bca Siswa Sekolah Dasar. Junal Respon Publik, 13(3), 85-89.

http://muarabakti.com/index.php. (2020). Desa Muara Bakti. Retrieved from http://muarabakti.com/about.php

http://www.bpkp.go.id/. (2020). Undang-Undang Dasar 1945 (Amandemen). In Undang-Undang Dasar 1945 (Amandemen). (pp. 1-19). Retrieved from http://www.bpkp.go.id/uu/file/1/9.bpkp

https://peraturan.bpk.go.id/. (2007). UU Nomor 43 Tahun 2007. Retrieved from https://peraturan.bpk.go.id/Home/Details/39968/uu-no-43-tahun-2007

Husadha, C., Winarso, W., Hidayat, W. W., Widjanarko, W., Suryati, A., \& Fikri, A. W. N. (2020). Pelatihan Strategi Peningkatan Pemasaran, Penjualan dan Pelaporan Akuntansi melalui Pembuatan Website di Yayasan Duta Bangsa Indonesia di Cikarang. Jurnal Pengabdian Kepada Masyarakat UBJ, 3(1), 11-20. https://doi.org/10.31599/jabdimas.v3i1.50

K Anwar. (2018). Kehidupan Masyarakat di Desa Muara Bakti.

Kholistin, L. (2008). Strategi Pembelajaran Tematik kelas awal di SD Muhammadiyah. EduSains, 2(5), 60-78. Retrieved from http://e-journal.iainpalangkaraya.ac.id/index.php/edusains/article/view/19/18

Maskurotunitsa, R. S., \& Rohmiyati, Y. (2016). Pemberdayaan Masyarakat Desa Kalisidi Kecamatan Ungaran Barat Kabupaten Semarang. Jurnal Ilmu Perpustakaan, 5(4), 81-90.

Nafisah, A. (2014). Arti Penting Perpustakaan Bagi Upaya Peningkatan Minat Baca Masyarakat. Jurnal Perpustakaan Libraria, 2(2), 70-81.

Sudarsana. (2014). Konsep Dasar Pembinaan Minat Baca, 1-49. Retrieved from http://repository.ut.ac.id/4222/1/PUST4421-M1.pdf 
Perpustakaan Desa Terhadap Minat Baca Lingkungan Desa Muara Bakti, Kabupaten Bekasi 